Available online at GSC Online Press Directory

GSC Biological and Pharmaceutical Sciences

e-ISSN: 2581-3250, CODEN (USA): GBPSC2

Journal homepage: https://www.gsconlinepress.com/journals/gscbps

(RESEARCH ARTICLE)

CrossMark \&lick for updates

\title{
Biochemical profiling of different extracts of Centratherium anthelminticum seeds and its synergistic, antimicrobial activity on clinical, drug resistant and standard strains of some common microorganisms
}

\section{Thara $\mathrm{KM}^{*}$}

Department of Biotechnology, University of Calicut, Thenjippalam, Malappuram District, Kerala, India, Pin-673635.

Publication history: Received on 10 January 2020; revised on 25 January 2020; accepted on 29 January 2020

Article DOI: https://doi.org/10.30574/gscbps.2020.10.1.0009

\begin{abstract}
Extracts of seeds of Centratherium anthelminticum was prepared by Bioassay guided fractionation using different solvents. Different extracts from the plant Centratherium anthelminticumwas biochemically analyzed for different bioactive components and properties. It shows an inhibitory action on different clinical strains within a range of 100 $500 \mu \mathrm{g} / \mathrm{ml}$.
\end{abstract}

Keywords: Antimicrobial activity; MRSA; HPLC; Centratherumanthelminticum; Biochemical profiling

\section{Introduction}

Centratherumanthelminticum (L) Kuntze., (Purple flebane) is a common ingredient in different ayurvedic preparations. The biological activities are related to the structure of the compound to an extent. Most important classes of biologically active compound belong to phenolic, flavonoids, alkaloids, terpenoids etc. Centratherum anthelminticum (L) Kuntze., (Purple flebane).

This plant belongs to the family Astearace and other common names are 'Kattujeerakam' 'Vanajeera', 'Aranyageera' and Kalijiri'. It is seen as herb in hilly areas and sub-tropical regions. Medicinal properties are vested in its seeds, roots, leaves etc. It is effective in treating thread worm infections and gastric troubles. Dry seeds were used in the present study [1].

\section{Material and methods}

Plant material: The seeds of Centratherum anthelminticum were collected from the plants Wayanad district, Kerala. It was identified by the Department of Botany, University of Calicut. Voucher no.7214 and was deposited in the herbarium.

Plant material and seeds were collected, washed air died and aqueous extract was prepared. The extract was prepared as by the method described by Thara et al., 2013[4].Different biochemical analysis were also performed for testing the presence of phenolics, flavanoids,terpenoids, saponins, glycosides and proteins[4],[5],[6],[7].HPLC profiling was also conducted as described earlier[4],[8].

\footnotetext{
${ }^{*}$ Corresponding author

E-mail address: tara_menon2003@yahoo.co.in
} 


\subsection{Test organisms}

\subsubsection{Standard strains}

Escherichia coli MTCC 41, Proteus vulgaris MTCC 426, Pseudomonas aeruginosa MTCC 424, Staphylococcus aureus MTCC 87, Candida albicans MTCC 183. These cultures were purchased from Institute of Microbial Technology (IMTECH), Chandigargh.Klebsilla pneumonia and Aspergillus niger were collected from the Department of Life Sciences, University of Calicut.

\subsubsection{Clinical strains}

The following clinical strains were also tested. The strains were collected from Department of Microbiology, Govt. Medical College, Calicut.Acenetobacter, Enterobacter, Klebsillia, Proteus mirabilis, Proteus vulgaris, Salmonella typii,Shigella and Staphylococcus aureus.

\subsubsection{MDR strains}

MRSA (ATCC 43300) -Collected from Jubilee mission medical college, Thrissur.

\subsection{Antibacterial activity}

\subsubsection{Determination of minimum inhibitory concentration (MIC)}

MICs for each extract against each microbial strains were determined using nutrient broth. $10 \mathrm{ml}$ of the medium was taken in a $50 \mathrm{ml}$ conical flask and sterilized. The extract (stock diluted to $10 \mathrm{mg} / \mathrm{ml}$ in DMSO) was then added to $10 \mathrm{ml}$ of medium in a series of conical flasks to get a concentration of 10000,1000,100,10, $0 \mu \mathrm{g} / \mathrm{ml}$ initially $(10$ times dilution). Then double dilution was used to determine the range of inhibitory activity (MIC value) of each extract. A loop-full of fresh culture at $\log$ phase $\left(1 \times 10^{8} \mathrm{CFU} / \mathrm{ml}\right.$, turbidity equal to that of 0.5 MacFarland solution) was added to each flask so as to have concentration of $5 \times 10^{5} \mathrm{CFU} / \mathrm{ml}$. It was then incubated at $36^{0}$ for 18 to $24 \mathrm{hrs}$. The OD at 600 $\mathrm{nm}$ was monitored at different concentrations of the drug in the culture media. The least concentration at which the growth of the organism was completely inhibited was recorded as MIC of that extract, comparing the OD with that of the blank. It was then confirmed by inoculating to fresh agar plate [9],[10],[11]. The experiment was done in triplicate and average value of MIC was then taken. It was then statistically analyzed and $\mathrm{p}<0.05$ was considered as significant. The experiment was repeated for different strains and extracts. The values were compared for gram positive and negative bacteria. The difference in inhibitory effect of the extract on the growth of clinical and standard strains was compared.

\subsubsection{Synergistic effect}

The method was done using a 96-well micro-titer plate. In this $200 \mu \mathrm{l}$ of the sterile nutrient broth was added to each well. In the first well of series 1, ie A1, antibiotic at a concentration of $100 \mu \mathrm{g} / \mathrm{ml}$ was added. In the well B1 sample AS1 at a concentration of $500 \mu \mathrm{g} / \mathrm{ml}$ was added. In the well C1 both antibiotic and AS1 were added. The concentration of the antibiotic and AS1 were the respective MICs or above the MIC values. All the wells were then serially diluted to next well.ie $100 \mu \mathrm{l}$ from first well has transferred to second and $100 \mu \mathrm{l}$ from second to third and so on so that a double dilution had obtained. All wells were then inoculated with culture at log phase, mixed well, covered and incubated at $36^{\circ} \mathrm{C}$ for $18 \mathrm{hrs}$. The growth was observed and MICs were noted and Fractional inhibitory concentrations (FICs) were calculated [12], [13].

Fractional inhibitory concentration (FIC) was calculated using the formula

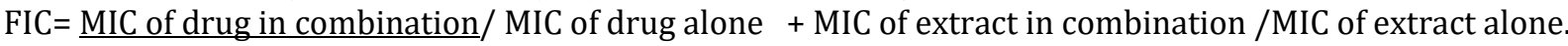

\subsection{Statistical analysis}

All data were analyzed using SPSS version 16.0.

\section{Results and discussion}

The yield of the aqueous extract was yield was 3.5\%. Biochemical analysis shows the presence of alkaloids, saponins and glycosides in aqueous extract (Table 2, 3). HPLC profiling shows two major peaks at RT 1.6 and 7.6 [Fig. 1]. Results of the in vitro anti-bacterial activity of the aqueous and methanol extract were summarized in Table 4 and 5. 
Table 1 Percentage yield of the extracts

\begin{tabular}{|c|c|c|c|c|c|}
\hline Name of the plant & Part used & Solvent & Yield & $\%$ yield & Designated as \\
\hline \multirow[t]{4}{*}{ Centratheriumanthelminticum } & Seeds & Methanol & 2.5 & 5.0 & CA1 \\
\hline & & Ethanol & 1.0 & 2.5 & $\mathrm{CA} 2$ \\
\hline & & Water & 1.1 & 2.8 & CA3 \\
\hline & & Chloroform & 0.1 & 0.20 & CA4 \\
\hline
\end{tabular}

Table 2 Various metabolites present in the extracts

\begin{tabular}{|c|c|c|c|c|c|c|c|c|}
\hline Name of the plant & $\begin{array}{l}\text { Extract } \\
\text { tested }\end{array}$ & $\begin{array}{l}\text { Phenolic } \\
\text { acids }\end{array}$ & Flavonoids & Alkaloids & Saponins & Glycosides & Terpenoids & Protein \\
\hline \multirow[t]{2}{*}{ Centratheriumanthelminticum } & $\mathrm{HCI}$ & ++ & + & + & - & - & - & - \\
\hline & $\mathrm{HC} 3$ & - & - & + & + & + & & ++ \\
\hline
\end{tabular}

+++ Present high level, ++ medium level, + low level,-- absent

Table 3 Total phenolics and flavonoids in the extracts

\begin{tabular}{|c|c|c|c|}
\hline Name of the plant & $\begin{array}{l}\text { Extract used for the } \\
\text { estimation }\end{array}$ & $\begin{array}{l}\text { Total phenolics as } \\
\text { Gallic acid } \\
\text { equivalents } \\
\text { (GE) }\end{array}$ & $\begin{array}{l}\text { Total flavanoids as } \\
\text { Quercetin } \\
\text { equivalents } \\
\text { (QE) }\end{array}$ \\
\hline \multirow[t]{2}{*}{ Centratheriumanthelminticum } & $\mathrm{HCI}$ & $8+3$ & $0.8+0.2$ \\
\hline & HC3 & 2.5 & ND \\
\hline
\end{tabular}


Table 4 Antimicrobial activity of extracts against standard strains: Micro dilution test.

\begin{tabular}{|c|c|c|c|c|c|c|c|c|}
\hline $\begin{array}{l}\text { Name of the } \\
\text { plant }\end{array}$ & $\begin{array}{l}\text { Extract used for } \\
\text { the estimation }\end{array}$ & $\begin{array}{l}\text { Escherichia } \\
\text { coli } \\
(\mu g / m l)\end{array}$ & $\begin{array}{l}\text { Pseudomonas } \\
\text { aeruginosa } \\
(\mu \mathrm{g} / \mathrm{ml})\end{array}$ & $\begin{array}{l}\text { K.pneumonia } \\
(\mu \mathrm{g} / \mathrm{ml})\end{array}$ & $\begin{array}{l}\text { Proteus } \\
\text { mirabilis } \\
(\mu \mathrm{g} / \mathrm{ml})\end{array}$ & $\begin{array}{l}\text { Staphylococcus } \\
\text { aureus } \\
(\mu \mathrm{g} / \mathrm{ml})\end{array}$ & $\begin{array}{l}\text { Candida } \\
\text { albicans } \\
(\mu g / m l)\end{array}$ & $\begin{array}{l}\text { Aspergillus } \\
\text { niger } \\
(\mu g / m I)\end{array}$ \\
\hline $\begin{array}{l}\text { Centratheriumant } \\
\text { helminticum }\end{array}$ & $\begin{array}{l}\mathrm{HCI} \\
\mathrm{HC} 3\end{array}$ & $\begin{array}{l}250 \\
220\end{array}$ & $\begin{array}{l}440 \\
200\end{array}$ & $\begin{array}{l}250 \\
150\end{array}$ & $\begin{array}{l}220 \\
150\end{array}$ & $\begin{array}{l}260 \\
160\end{array}$ & $\begin{array}{l}450 \\
250\end{array}$ & $\begin{array}{l}\mathrm{ND} \\
\mathrm{ND}\end{array}$ \\
\hline Gentamicin & GEN & 30 & 30 & & & & & \\
\hline Streptomycin & SRT & 50 & 40 & & & & & \\
\hline $\begin{array}{l}\text { Penicillin } \\
\text { Nystatin }\end{array}$ & $\begin{array}{l}\text { PEN } \\
\text { NYS }\end{array}$ & $\begin{array}{l}10 u \\
40 u\end{array}$ & $\begin{array}{l}10 \mathrm{IU} \\
40\end{array}$ & & & & & \\
\hline DMSO & DMSO & - & - & & & & & \\
\hline Water (sterile) & & - & - & & & & & \\
\hline Ampicillin & & $10 \mathrm{mcg}$ & & & & & & \\
\hline
\end{tabular}

Table 5 Antimicrobial activity of extracts against clinical strains

\begin{tabular}{|c|c|c|c|c|c|c|c|c|c|}
\hline $\begin{array}{l}\text { Name of } \\
\text { the plant }\end{array}$ & $\begin{array}{l}\text { Extract } \\
\text { used }\end{array}$ & $\begin{array}{l}\text { Shigellaflexi } \\
\text { neri } \\
(\mu \mathrm{g} /)\end{array}$ & $\begin{array}{l}\text { Escherichia } \\
\text { coli } \\
(\mu \mathrm{g} / \mathrm{ml})\end{array}$ & $\begin{array}{l}\text { Klebsiella } \\
\text { pneumonia } \\
(\mu \mathrm{g} / \mathrm{ml})\end{array}$ & $\begin{array}{l}\text { Proteus } \\
\text { vulgaris } \\
(\mu \mathrm{g} / \mathrm{ml})\end{array}$ & $\begin{array}{l}\text { Staphylococc } \\
\text { us aureus } \\
(\mu \mathrm{g} / \mathrm{m} \mathrm{l})\end{array}$ & $\begin{array}{l}\text { Enterobacter } \\
(\mu \mathrm{g} / \mathrm{ml})\end{array}$ & $\begin{array}{l}\text { Acinetobact } \\
\text { er } \\
(\mu \mathrm{g} / \mathrm{ml})\end{array}$ & $\begin{array}{l}\text { Proteous } \\
\text { mirabilis } \\
\text { Salmonela } \\
(\mu \mathrm{g} / \mathrm{ml}) \\
\text { typhi }\end{array}$ \\
\hline \multirow{4}{*}{$\begin{array}{l}\text { Hemigrap } \\
\text { hiscolorat } \\
\text { a, (Blume) } \\
\text { Hallier } \mathrm{f} \text {. }\end{array}$} & $\mathrm{HCI}$ & & & & & & & & 150 \\
\hline & HC3 & 150 & 200 & 150 & 212 & 250 & 175 & 300 & 150 \\
\hline & & 145.6 & 180 & 140 & 200 & 220 & 200 & 150 & 175 \\
\hline & & & & & & & & & 150 \\
\hline
\end{tabular}


Table 6 MICs of extracts on MRSA (ATCC 43300)-Tube dilution test.

\begin{tabular}{|c|c|c|}
\hline Name of the plant & $\begin{array}{l}\text { Extract used for the } \\
\text { estimation }\end{array}$ & MRSA $(\mu \mathrm{g} / \mathrm{ml})$ \\
\hline $\begin{array}{l}\text { Centratherium } \\
\text { anthelminticum }\end{array}$ & $\mathrm{HCI}$ & 200 \\
\hline $\begin{array}{l}\text { Centratherium } \\
\text { anthelminticum }\end{array}$ & HC3 & 100 \\
\hline
\end{tabular}

Table 7 FIC of different extracts in combination with antibiotics against Staphylococcus aureus and Escherichia coli.

\begin{tabular}{|c|c|c|c|c|c|c|c|}
\hline Microorganism tested & $\begin{array}{l}\text { Extract used in } \\
\text { combination }\end{array}$ & Antibiotic used & $\begin{array}{l}\text { MIC of } \\
\text { antibiotic } \\
\text { alone }\end{array}$ & $\begin{array}{l}\text { MIC of antibiotic in } \\
\text { combination }\end{array}$ & $\begin{array}{l}\text { MIC of } \\
\text { extract } \\
\text { alone }\end{array}$ & $\begin{array}{l}\text { MIC of extract in } \\
\text { combination }\end{array}$ & FIC INDEX \\
\hline Staphylococcus aureus & HC3 & Penicillin & 20 & 7.0 & 250 & 150 & 0.95 \\
\hline E.coli & HC3 & Gentamicin & 15 & 6.0 & 250 & 200 & 1.0 \\
\hline
\end{tabular}


Aqueous extract showed significantly higher activity against microbes test compared with methanol extract. It showed maximum activity against $S$. aureus and K. pneumonia. The activity against clinical strains was also significant. It showed significant activity against C.albicans also. The extract showed good activity against drug resistant organism like MRSA [Table 6]. It showed synergistic effect against the microbes when tested along with antibiotics. When treated along with pencillin the concentration of pencillin was significantly reduced to less than half-fold [Table 7]. Plants are alternative source of medicines $[14,15,16]$. Present study shows $C$. anthelminticum is a potential source against microbial diseases.

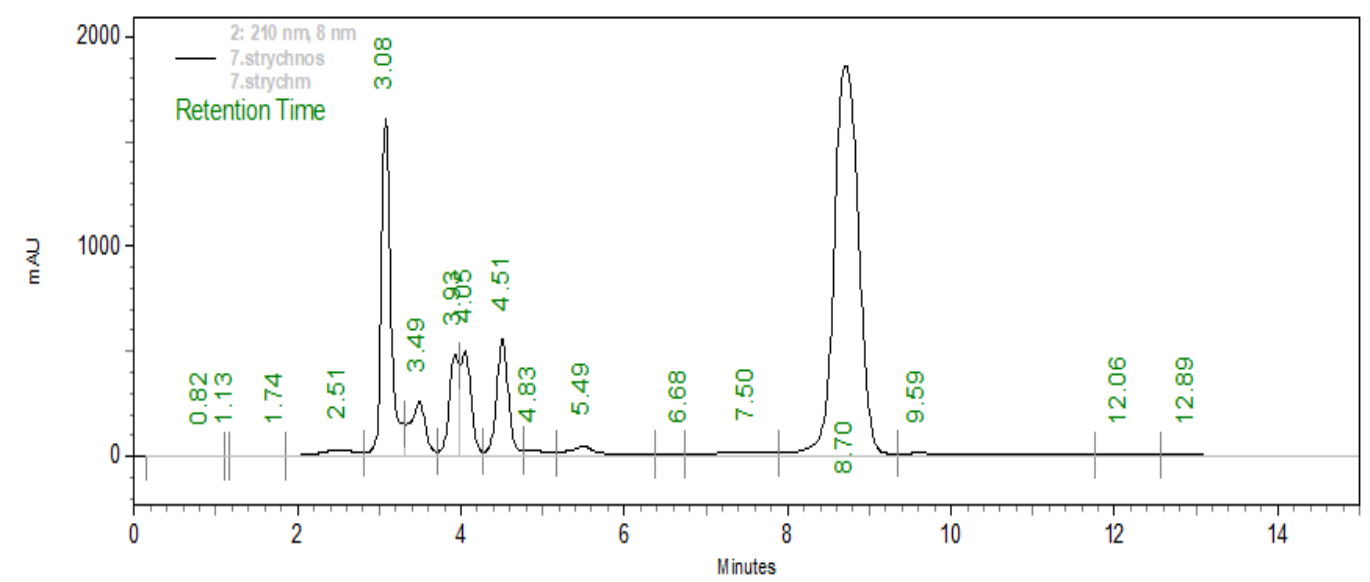

Figure 1 HPLC fingerprint of methanol extract of Centratherium anthelminticum

\begin{tabular}{llllllll}
\hline 2: 210 nm, $\mathbf{~ n m}$ & & & & & & \\
\hline Pk \# & $\begin{array}{l}\text { Retention } \\
\text { Time }\end{array}$ & Area & Area \% & Height & $\begin{array}{l}\text { Height } \\
\text { \% }\end{array}$ & $\begin{array}{l}\text { Start } \\
\text { Time }\end{array}$ & $\begin{array}{l}\text { Stop } \\
\text { Time }\end{array}$ \\
\hline 1 & 0.82 & 13231 & 0.02 & 300 & 0.01 & 0.14 & 1.11 \\
2 & 1.13 & 634 & 0.00 & 214 & 0.00 & 1.11 & 1.16 \\
3 & 1.74 & 56952 & 0.08 & 2419 & 0.04 & 1.16 & 1.85 \\
4 & 2.51 & 904046 & 1.19 & 31504 & 0.58 & 1.85 & 2.81 \\
5 & 3.08 & 13500610 & 17.84 & 1604062 & 29.61 & 2.81 & 3.32 \\
6 & 3.49 & 3452380 & 4.56 & 259187 & 4.78 & 3.32 & 3.71 \\
7 & 3.93 & 4097439 & 5.42 & 482020 & 8.90 & 3.71 & 3.99 \\
8 & 4.05 & 4417337 & 5.84 & 497379 & 9.18 & 3.99 & 4.28 \\
9 & 4.51 & 5728857 & 7.57 & 556158 & 10.27 & 4.28 & 4.77 \\
10 & 4.83 & 535907 & 0.71 & 26074 & 0.48 & 4.77 & 5.17 \\
11 & 5.49 & 1345632 & 1.78 & 46849 & 0.86 & 5.17 & 6.37 \\
12 & 6.68 & 202812 & 0.27 & 9504 & 0.18 & 6.37 & 6.74 \\
13 & 7.50 & 1027991 & 1.36 & 22079 & 0.41 & 6.74 & 7.88 \\
14 & 8.70 & 38969965 & 51.50 & 1859639 & 34.33 & 7.88 & 9.34 \\
15 & 9.59 & 981843 & 1.30 & 13427 & 0.25 & 9.34 & 11.77 \\
16 & 12.06 & 151680 & 0.20 & 3264 & 0.06 & 11.77 & 12.57 \\
17 & 12.89 & 279929 & 0.37 & 3169 & 0.06 & 12.57 & 15.53 \\
\hline Totals & & $\mathbf{7 5 6 6 7 2 4 5}$ & $\mathbf{1 0 0 . 0 0}$ & $\mathbf{5 4 1 7 2 4 8}$ & $\mathbf{1 0 0 . 0 0}$ & & \\
\hline & & & & & & & \\
\hline
\end{tabular}


HPLC chromatogram at $210 \mathrm{~nm}$ shows the presence of three major compounds with retention time $3.08 \mathrm{~min}, 4.51 \mathrm{~min}$ and $8.7 \mathrm{~min}$ and area of $13500610 \mathrm{mAu} 5728857 \mathrm{mAu}$ and $38969965 \mathrm{mAu}$ respectively.

\section{Conclusion}

We can conclude that Centratherium anthelminticumhas the potential source to develop into an antimicrobial agent. Both methanol and aqueous and methanol extract showed significant effect against standard and clinical strains respectively. It has synergistic effect with certain antibiotics also against E.coli as well as S.aureus. This has to be further studied as a combating strategy against drug resistance.

\section{Compliance with ethical standards}

\section{Acknowledgments}

I acknowledge University of Calicut for providing the facilities to carry out the work.

\section{References}

[1] Ann MB andZigang D. (2011).2- Epigallocatechin 3-Gallate and Green Tea Catechins: United They Work, Divided They Fail.,Cancer Prev Res, 8(2), 514-519.

[2] Thara KM, Zuhara KF and Raji TK. (2013). Inhibitory and synergistic effect of Pterocarpusmarsupeum extracts on clinical and standard strains of microorganisms and its biochemical analysis. Indo american journal of pharmaceutical research. Indo American Journal of Pharm Research, 3, 5583-5593.

[3] Harborne JB. (1989). Methods in plant biochemistry, In: Plant phenolics: Academic Press, London, UK.

[4] Kessler MU and Jung L. (2003). Anti prooxidant activity of rutin and quercetinderivatives.J.Pharm.Pharmacol, 55(4), 131-142.

[5] Mahesh B and Satish S. (2008). Antimicrobial Activity of Some Important Medicinal Plant Against Plant and Human Pathogens. World Journal of Agricultural Sciences, 4, 839-843.

[6] McDonald S, Prenzler PD, Autolovich M and Robards K. (2001). Phenolic content and antioxidant activity of olive extracts. Food Chemistry, 73(5), 73-84.

[7] Singleton VL, Orthofer R and Lamuela-Raventos RM. (1999). Analysis of total phenols andother oxidation substrates and antioxidants bymeans of Folin-Ciocalteau reagent. Methods Enzymol, 299, 152-178.

[8] Bauer AW, Kirby WMM, Sherris JC and Turk M. (1966). Antibiotic susceptibility testing by a standardized single disc method. Am J ClinPathol, 45(8), 493-496.

[9] Kamicker BJ, Michael TS, Frank K. Fadia DH, Wenchi S, Kim C, Joan D and Thomas DG. (2008). Bacterial Efflux Pump Inhibitors. From: Methods in Molecular Medicine, Vol. 142: New Antibiotic Targets, Edited by: W. Scott Champney (C) Humana Press Inc., Totowa, NJ.

[10] Masoodi MH, Bahar A, Iqbal MZ, Saroor AK, Shamshir K and Singh P. (2008). Antibacterial activity of whole plant extract of Marrubiumvulgare. African Journal of Biotechnology, 7(2), 86-87.

[11] Parekh J, Karathia N and Chanda S. (2006). Screening of some traditionally used medicinal plants for potential antibacterial activity. Indian Journal of Pharmaceutical Science, 68(6), 832-834.

[12] Patel S, Shah, RS and Goyal R. (2006). Antihyperglycemic, antihyperlipidemicand antioxidant effects of Dihar, a polyherbal ayurvedic formulation in streptozotocin induced diabetic rats. Indian Journal of Experimental Biology, 47, 35-39.

[13] Siwaporn P, Michael J, Mulvany Y, AllenbachV, Andrew M, Kurt H, Poungpen S and Chaweewan J. (2011). Effects of an n-butanol extract from the stem of Tinosporacrispa on blood pressure and heart rate in anesthetize ratsJournal of Ethnopharmacology, 133, 675-686.

[14] Swami S, Raja Chakraborty C, Sridhar YSR and Biplab D. (2010). Free radicals, antioxidants, diseases and phytomedicines: current status and future prospect international journal of Pharmaceutical Sciences Review and Research, 3, 235-240. 
[15] Khare C. (2007).Centratherumanthelminticum Kuntze. In: Khare C. (eds) Indian Medicinal Plants. Springer, New York, NY.

[16] ToobaLateef, Shamim A and QureshN.(2016).Centratherumanthelminticum and Withaniacoagulans Improves Lipid Profile and Oxidative Stress in Triton X-100 induced Hyperlipidemic Rabbits, International Journal of Pharmacognosy and Phytochemical Research, 8(6).

\section{How to cite this article}

Thara KM. (2020). Biochemical profiling of Centratheriumanthelminticum and its synergistic, antimicrobial activity of on clinical drug resistant and standard strains of some common microorganisms. GSC Biological and Pharmaceutical Sciences, 10(1), 118-125. 